Correspondence Mike L. Dyall-Smith mike.dyallsmith@gmail.com

\section{Halonotius pteroides gen. nov., sp. nov., an extremely halophilic archaeon recovered from a saltern crystallizer}

\author{
David G. Burns, ${ }^{1}$ Peter H. Janssen, ${ }^{2}$ Takashi Itoh, ${ }^{3}$ Masahiro Kamekura, ${ }^{4}$ \\ Akinobu Echigo ${ }^{5}$ and Mike L. Dyall-Smith ${ }^{6}$ \\ ${ }^{1}$ Microbiological Diagnostic Unit, University of Melbourne, Parkville 3052, Australia \\ ${ }^{2}$ Grasslands Research Centre, Tennent Drive, Private Bag 11008, Palmerston North 4442, \\ New Zealand \\ ${ }^{3}$ Japan Collection of Microorganisms, RIKEN BioResource Center, Saitama 351-0198, Japan \\ ${ }^{4}$ Halophiles Research Institute, 677-1 Shimizu, Noda-shi, Chiba 278-0043, Japan \\ ${ }^{5}$ Bio-Nano Electronics Research Centre, Toyo University, 2100, Kujirai, Kawagoe, \\ Saitama 350-8585, Japan \\ ${ }^{6}$ Max Planck Institute of Biochemistry, Department of Membrane Biochemistry, \\ Am Klopferspitz 18, D-82152 Martinsried, Germany
}

\begin{abstract}
Strains $1.15 .5^{\top}, 2.27 .5,5.24 .4$ and 6.14 .5 were isolated from a solar saltern. They have flattened, rod-shaped cells and are aerobic, extremely halophilic members of the domain Archaea and family Halobacteriaceae. Cells stained Gram-negative and grew optimally in media around neutral $\mathrm{pH}$ and containing $20-24 \%(\mathrm{w} / \mathrm{v})$ (strains $1.15 .5^{\top}$ and 2.27 .5$)$ or $22-24 \%(\mathrm{w} / \mathrm{v})(5.24 .4$ and 6.14 .5$)$ salts. $\mathrm{Mg}^{2+}$ was not required. The DNA G+C contents of these isolates were all close to $58 \mathrm{~mol} \%$, and DNA-DNA cross-hybridization showed a mean relatedness of $77 \%$. Their $16 \mathrm{~S}$ rRNA gene sequences differed by no more than $1.6 \%$ from each other. Phylogenetic tree reconstructions with other recognized members of the Halobacteriaceae indicated that they formed a distinct clade, with the closest relative being Halorubrum saccharovorum (86.6-87.6\% $16 \mathrm{~S}$ rRNA gene sequence similarity to the type strain). The only major polar lipid of all four isolates was the sulfated diglycosyl diether lipid S-DGD-1. By phase-contrast microscopy, the long, flattened cells of these strains often displayed a 'wing-like' shape. The phenotypic and phylogenetic data support the placement of these isolates into a novel species in a new genus within the Halobacteriaceae, for which we propose the name Halonotius pteroides gen. nov., sp. nov. The type strain of Halonotius pteroides is $1.15 .5^{\top}\left(=\mathrm{JCM} 14355^{\top}=\mathrm{CECT} 7525^{\top}\right.$ $\left.=\mathrm{DSM} 18729^{\mathrm{T}}\right)$, with the additional reference strains 2.27 .5 (=JCM $\left.14356=\mathrm{DSM} 18671\right)$, 5.24.4 (=JCM 14357 =DSM 18673) and 6.14.5 (=JCM $14358=$ DSM 18692).
\end{abstract}

In a previous study, we described the cultivation and diversity of haloarchaea in an Australian saltern crystallizer (Burns et al., 2004). One of the dominant groups, representing $16 \%$ of the population, formed a phylogenetically novel clade, and appeared to be specifically related to sequences previously recovered from Deep Lake (Bowman et al., 2000), a hypersaline lake in Antarctica. We referred to this clade, which consisted of $16 \mathrm{~S}$ rRNA gene sequences from isolates and cloned genes, as the 'Antarctic Deep Lake group' (Burns et al., 2004). The characteristics of four

The GenBank/EMBL/DDBJ accession numbers for the 16S rRNA gene sequences of isolates $1.15 .5^{\top}, 2.27 .5,5.24 .4$ and 6.14.5 are AY498641, AY498646, EF090605 and AY498648, respectively. isolates from that group, $1.15 .5^{\mathrm{T}}, 2.27 .5,5.24 .4$ and 6.14 .5 , are presented here.

The minimal standards for the description of new taxa within the order Halobacteriales were followed (Oren et al., 1997), using previously described methods (Burns et al., 2007; Gutierrez et al., 2002; Torreblanca et al., 1986). For growth/activity tests, cells were inoculated into characterization medium CM (Burns et al., 2007), with or without the addition of a specific nutrient. Reference strains included Haloferax volcanii NCIMB $2012^{\mathrm{T}}$, Halogeometricum borinquense JCM $10706^{\mathrm{T}}$, Haloterrigena turkmenica JCM $9101^{\mathrm{T}}$, Halomicrobium mukohataei JCM $9738^{\mathrm{T}}$ and Halobiforma haloterrestris $\mathrm{JCM} 11627^{\mathrm{T}}$. All cultures were incubated unshaken at $37{ }^{\circ} \mathrm{C}$, unless stated otherwise. 
Colonies took 4-8 weeks to grow on solid media, optimally on DBCM2 medium, with pyruvate as a carbon/energy source (Burns \& Dyall Smith, 2006), and with agar (1.5\%, $\mathrm{w} / \mathrm{v}$; Difco Bacto) or agarose as the gelling agent. After 8 weeks, colonies were small $(0.5-1.0 \mathrm{~mm}$ diameter $)$, convex, round, with an entire edge and an intense red colour. Liquid cultures were also red or pink in colour, depending upon the cell density. Under optimal growth conditions, cells displayed a range of flattened, angular or rounded shapes, but many were flat rods, often with rounded ends, resembling the wings of small insects (Fig. 1).

All strains were Gram-negative. By phase-contrast light microscopy, about $1-5 \%$ of cells exhibited weak motility, and transmission electron microscopy revealed that the cells possessed polar flagella. Growth was tested using a wide range of substrates (see species description) but, under the characterization conditions used, cells were able to grow only on glucose, glycerol or pyruvate. Cells were oxidase- and catalase-negative using conventional testing. All strains were unable to use nitrate (with or without L-arginine) or DMSO as alternative electron acceptors under anaerobic conditions.

The optimum temperature for growth was $37-40{ }^{\circ} \mathrm{C}$, depending on the strain, and no growth was observed at 4 or $55{ }^{\circ} \mathrm{C}$. Growth occurred over a wide range of $\mathrm{NaCl}$ concentration, from a minimum of $16 \%$ up to saturation. The optimum salinity was $20-24 \%(\mathrm{w} / \mathrm{v})$ for strains $1.15 .5^{\mathrm{T}}$ and 2.27.5 and $22 \%(\mathrm{w} / \mathrm{v})$ for strains 5.24.4 and 6.14.5. All strains had no minimal magnesium ion requirement, but poor growth was observed in the absence of $\mathrm{Mg}^{2+}$ ions, and low to no growth occurred above $1.25 \mathrm{M} \mathrm{Mg}^{2+}$. Optimum growth varied with respect to both $\mathrm{Mg}^{2+}$-associated anion and isolate. Strain $1.15 .5^{\mathrm{T}}$ had equal optima of $0.4 \mathrm{M}$ for $\mathrm{MgCl}_{2}$ and $\mathrm{MgSO}_{4}$, while strains 2.27.5 and 5.24.4 shared a $\mathrm{MgSO}_{4}$ optimum of $0.4 \mathrm{M}$ but had respective $\mathrm{MgCl}_{2}$ optima of 0.6 and $0.2-0.4 \mathrm{M}$. Isolate 6.14 .5 had the broadest

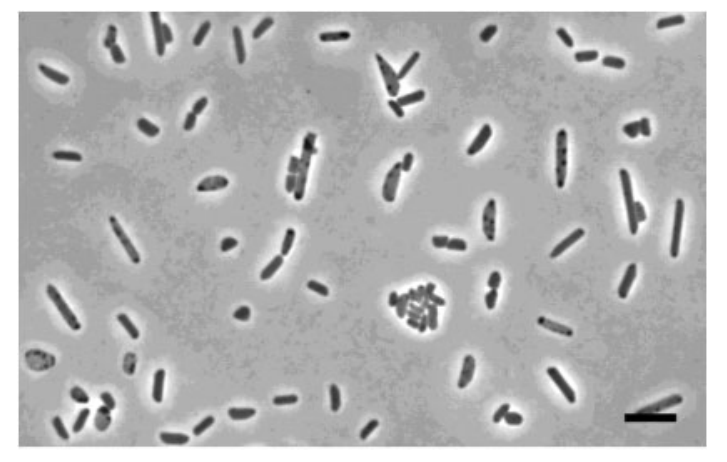

Fig. 1. Phase-contrast image of cells of isolate $1.15 .5^{\top}$ grown under optimum conditions. Cells display some pleomorphism, with flattened rods and other flattened shapes. Many of these have shapes that resemble the wings of insects. The other Halonotius isolates $(2.27 .5,5.24 .4$ and 6.14.5) exhibited similar morphologies (not shown). Bar, $10 \mu \mathrm{m}$. optima of all strains, demonstrating a $\mathrm{MgSO}_{4}$ optimum of $0.2-0.6 \mathrm{M}$ and a $\mathrm{MgCl}_{2}$ optimum of $0.4-0.8 \mathrm{M}$.

All isolates had similar responses to $\mathrm{pH}$, exhibiting growth over the range $\mathrm{pH}$ 5.5-8.5. Optimum growth was at $\mathrm{pH} 7.0-7.5$ for isolates $1.15 .5^{\mathrm{T}}$ and 2.27 .5 and $\mathrm{pH} 7.0$ for 5.24.4 and 6.14.5. The antibiotic sensitivities of the isolates were typical of halobacteria (see species description).

The polar lipids of the four isolates were identical by TLC (Fig. 2, lanes 1-4). In addition to phosphatidylglycerol and phosphatidylglycerophosphate methyl ester, the isolates possessed a glycolipid with the same mobility as the sulfated diglycosyl diether lipid S-DGD-1 of Halomicrobium mukohataei JCM $9738^{\mathrm{T}}$ (Oren et al., 2002).

The DNA G $+\mathrm{C}$ contents of the strains, determined by the HPLC method of Tamaoka (1994), were $58.4 \mathrm{~mol} \%\left(1.15 .5^{\mathrm{T}}\right.$ and 5.24.4) and $58.7 \mathrm{~mol} \%$ (2.27.5 and 6.14.5). 16S rRNA gene sequences (Burns et al., 2004) were identical for strains

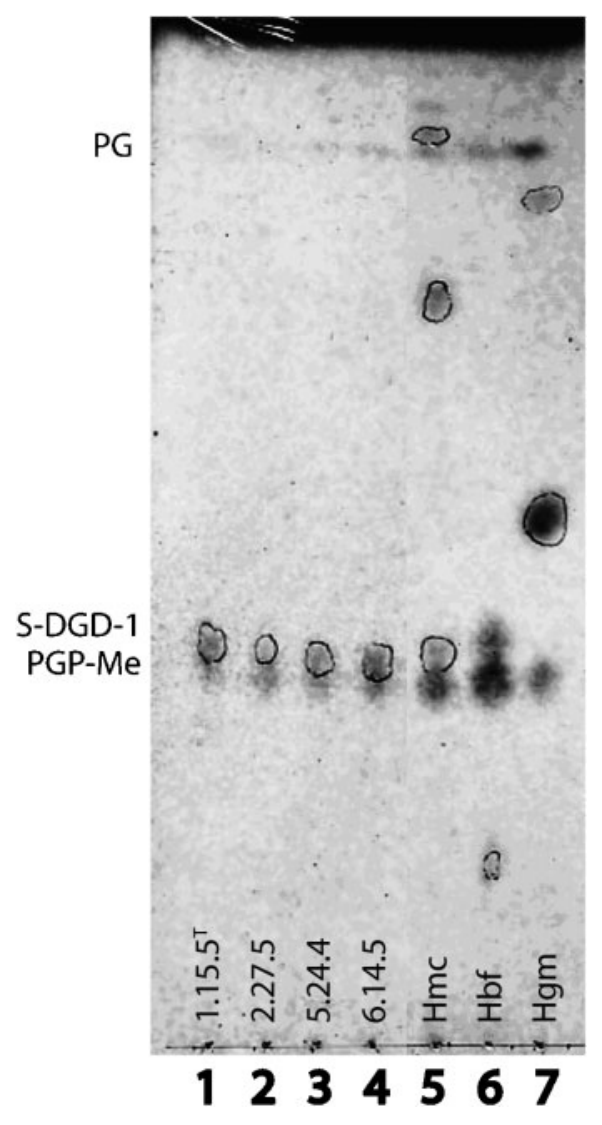

Fig. 2. TLC of polar lipids extracted using methods described by Kamekura (1993). Lanes: 1 , strain $1.15 .5^{\top} ; 2$, strain $2.27 .5 ; 3$, strain 5.24.4; 4, strain 6.14.5; 5, Halomicrobium mukohataei JCM 9738 ${ }^{\top}$; 6, Halobiforma haloterrestris JCM $11627^{\top} ; 7$, Halogeometricum borinquense JCM 10706 ${ }^{\top}$. PG, Phosphatidylglycerol; PGP-Me, phosphatidylglycerophosphate methyl ester; S-DGD-1, sulfated diglycosyl diether lipid. Glycolipids were detected as purple spots, which are circled. 
2.27.5 and 5.24.4, while the sequences of the other two strains differed from each other by less than $1.7 \%$. Among recognized members of the Halobacteriaceae, the closest relatives were the type strains of Halorubrum saccharovorum (86.6-87.6\% sequence similarity), Haloferax volcanii (86.3$86.8 \%)$ and Halogeometricum borinquense (85.5-87\%). DNA-DNA cross-hybridization, using the method of Ezaki et al. (1989), confirmed the close relationship between these strains, with isolate $1.15 .5^{\mathrm{T}}$ showing $72-$ $93 \%$ relatedness to the other three strains. Together, these data indicate that the four isolates belong to the same species. Phylogenetic tree reconstructions using $16 \mathrm{~S}$ rRNA gene sequences placed these isolates as a separate clade within the family Halobacteriaceae (Fig. 3).

The phenotypic characterization and phylogenetic data support the placement of these isolates in a novel species and a new genus within the Halobacteriaceae, for which we propose the name Halonotius pteroides gen. nov., sp. nov. Table 1 summarizes the distinguishing characteristics of the proposed genus from the most closely related genera.

\section{Description of Halonotius gen. nov.}

Halonotius (Ha.lo.no'ti.us. Gr. masc. n. hals, halos salt; L. masc. adj. notius southern; N.L. masc. n. Halonotius a salty southern one).

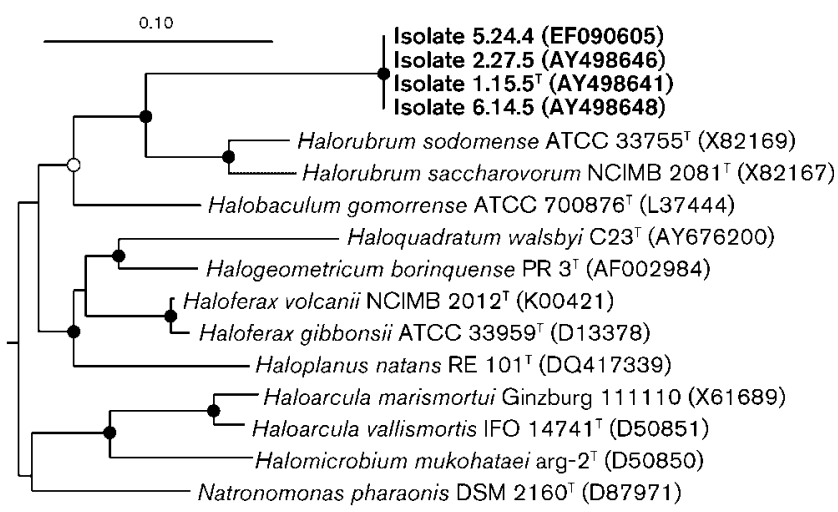

Fig. 3. Phylogenetic tree reconstruction showing relative placement of the novel strains. The tree is based on complete or nearly complete ( $>1300 \mathrm{nt})$ 16S rRNA gene sequences from organisms with validly published names. The tree shown was derived by maximum-likelihood, using the ARB package (Ludwig et al., 2004). Distance matrix and parsimony methods gave similar topologies (not shown). Bar, 0.10 expected nucleotide substitutions per site. Bootstrap values (using distance matrix methods) were derived from 1000 replicates and significant nodes ( $>75 \%)$ are indicated by filled circles at branch points. The node indicated by an open circle was less well supported ( $>50 \%$ but $<75 \%$ ). The outgroup sequences (not shown) consisted of sequences representing most of the other genera of the Halobacteriaceae as well as that of Methanosaeta concilii strain Opfikon (GenBank accession no. X16932.1).
Gram-negative, flat rods, often with rounded ends. Aerobic heterotrophs. Oxidase and catalase tests are negative. The genus belongs phylogenetically to the family Halobacteriaceae. Known habitats are salt lakes and saltern crystallizer ponds. The type species is Halonotius pteroides. Following the published guidelines (Oren \& Ventosa, 2000), we propose the three-letter genus abbreviation Hns.

\section{Description of Halonotius pteroides sp. nov.}

Halonotius pteroides [pte.ro.i' des. Gr. n. pteron wing; Gr. adj. (e) ides like; N.L. masc. adj. pteroides wing-like, named after the shape of many of the cells, which are flattened rods with rounded ends that appear similar to the wings of small insects].

Displays the following properties in addition to those given for the genus. Cells are flattened and display some variability in morphology, but many are flat rods, 0.7$1.5 \mu \mathrm{m}$ wide and $2-6 \mu \mathrm{m}$ long (Fig. 1). The ends of the rods are often rounded. Weakly motile with polar flagella. Colonies on agar medium are red with entire edges. Strictly aerobic; only oxygen is used as the final electron acceptor. Cannot utilize nitrate or DMSO as alternative electron acceptors. Growth occurs at pH 5.5-8.5, $25-45^{\circ} \mathrm{C}$ and $16-$ $36 \%(\mathrm{w} / \mathrm{v}) \mathrm{NaCl}$. Cells lyse immediately in distilled water. Optimal growth occurs under neutrophilic conditions, above $18 \%(\mathrm{w} / \mathrm{v})$ salinity. Capable of growing in defined media, but very restricted in the substrates utilized. Grows best on pyruvate, but also capable of utilizing glucose or glycerol as sole carbon sources. Does not grow with any of the following substrates as the sole carbon and energy source (all at $10 \mathrm{mM}$ ): acetate, alanine, arabinose, arginine, aspartate, benzoate, betaine, butanol, butyrate, cellobiose, citrate, ethanol, formate, fructose, fumarate, galactose, galacturonate, gluconuronate, glycine, glycolate, lactate, lactose, leucine, lysine, malate, malonate, mannitol, mannose, methanol, propanol, propionate, ribose, serine, succinate, sucrose, tartrate, threonine, urea, valine and xylose. Does not grow on cellulose, chitin or starch (each at $0.1 \%, \mathrm{w} / \mathrm{v})$. Acid is not produced from carbohydrate utilization. Negative for $\beta$-galactosidase activity and indole production. Sensitive to anisomycin, novobiocin, rifampicin and simvastatin, and resistant to ampicillin, bacitracin, chloramphenicol, cycloheximide, erythromycin, kanamycin, mycostatin, neomycin, streptomycin and tetracycline at $50 \mu \mathrm{g} \mathrm{ml}^{-1}$. All four known strains were isolated from solar saltern crystallizer ponds.

The type strain is $1.15 .5^{\mathrm{T}}\left(=\mathrm{JCM} 14355^{\mathrm{T}}=\right.$ CECT $7525^{\mathrm{T}}$ $=$ DSM $18729^{\mathrm{T}}$ ), isolated from Cheetham Salt Works, Geelong, Australia, with additional reference strains 2.27.5 $(=\mathrm{JCM} 14356=\mathrm{DSM} 18671), \quad 5.24 .4 \quad(=\mathrm{JCM} 14357$ $=\mathrm{DSM} 18673)$ and $6.14 .5(=\mathrm{JCM} 14358=\mathrm{DSM} 18692)$.

\section{Acknowledgements}

The authors thank Professor Dr Hans G. Trüper for his advice regarding nomenclature. D.G.B. was supported by an Australian 
Table 1. Phenotypic and other characteristics that distinguish strain $1.15 .5^{\top}$ from closely related genera

Data for related genera were taken from Oren (2006) and Cui et al. (2007). +, Positive; -, negative; \pm , variable; ND, no data available.

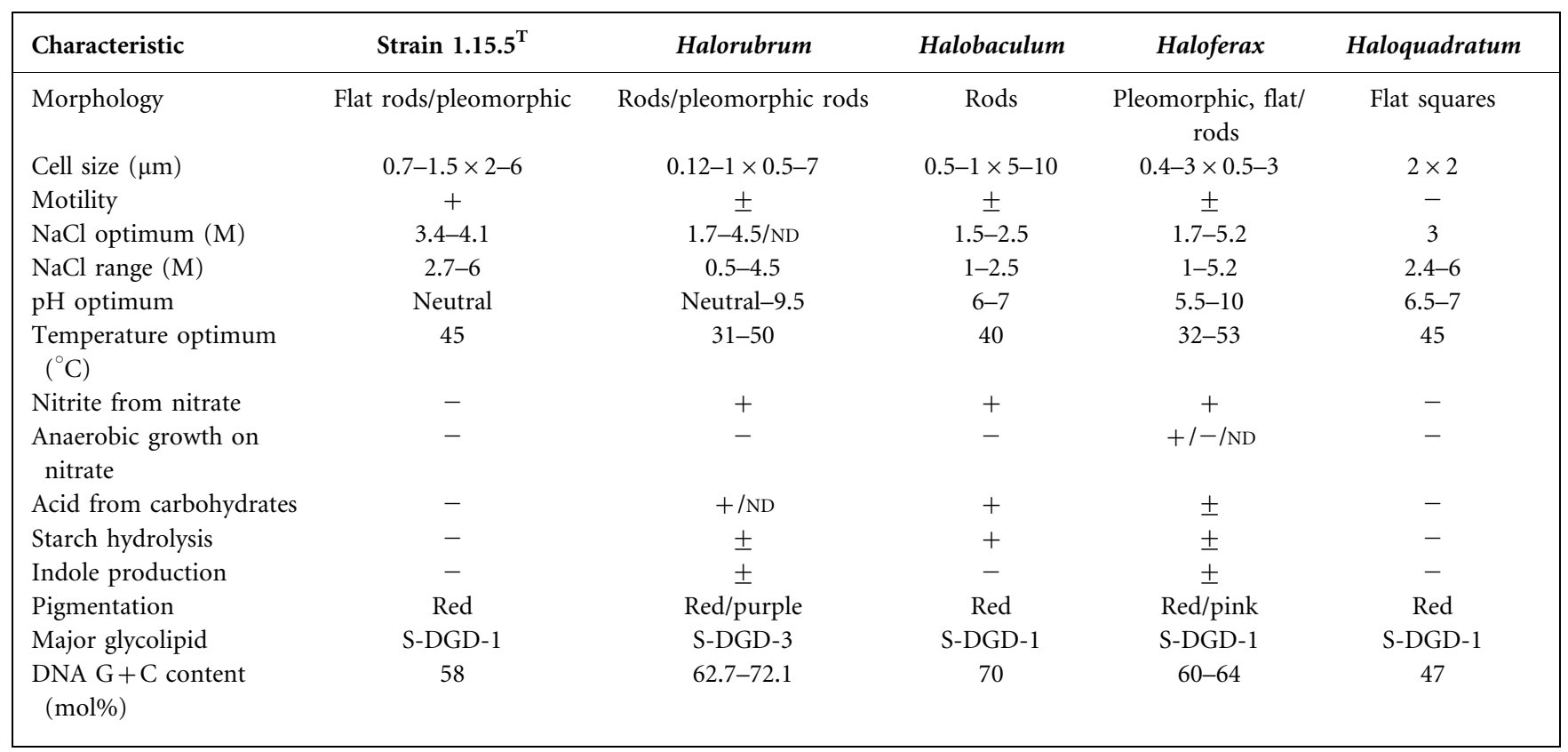

Post-graduate Award. We thank Wally Rickard and the staff of Cheetham Salt Ltd (Geelong) for their assistance and support. M. L.D.-S. is grateful to the MPI for their support.

\section{References}

Bowman, J. P., McCammon, S. A., Rea, S. M. \& McMeekin, T. A. (2000). The microbial composition of three limnologically disparate hypersaline Antarctic lakes. FEMS Microbiol Lett 183, 81-88.

Burns, D. G. \& Dyall Smith, M. (2006). Cultivation of haloarchaea. Methods Microbiol 35, 535-552.

Burns, D. G., Camakaris, H. M., Janssen, P. H. \& Dyall-Smith, M. L. (2004). Combined use of cultivation-dependent and cultivationindependent methods indicates that members of most haloarchaeal groups in an Australian crystallizer pond are cultivable. Appl Environ Microbiol 70, 5258-5265.

Burns, D. G., Janssen, P. H., Itoh, T., Kamekura, M., Li, Z., Jensen, G., Rodríguez-Valera, F., Bolhuis, H. \& Dyall-Smith, M. L. (2007). Haloquadratum walsbyi gen. nov., sp. nov., the square haloarchaeon of Walsby, isolated from saltern crystallizers in Australia and Spain. Int J Syst Evol Microbiol 57, 387-392.

Cui, H. L., Lin, Z. Y., Dong, Y., Zhou, P. J. \& Liu, S. J. (2007). Halorubrum litoreum sp. nov., an extremely halophilic archaeon from a solar saltern. Int J Syst Evol Microbiol 57, 2204-2206.

Ezaki, T., Hashimoto, Y. \& Yabuuchi, E. (1989). Fluorometric deoxyribonucleic acid-deoxyribonucleic acid hybridization in microdilution wells as an alternative to membrane filter hybridization in which radioisotopes are used to determine genetic relatedness among bacterial strains. Int J Syst Bacteriol 39, 224-229.

Gutierrez, M. C., Kamekura, M., Holmes, M. L., Dyall-Smith, M. L. \& Ventosa, A. (2002). Taxonomic characterization of Haloferax sp. (" $H$. alicantei") strain Aa 2.2: description of Haloferax lucentensis sp. nov. Extremophiles 6, 479-483.

Kamekura, M. (1993). Lipids of extreme halophiles. In The Biology of Halophilic Bacteria, pp. 135-161. Edited by R. H. Vreeland \& L. I. Hochstein. Boca Raton, FL: CRC Press.

Ludwig, W., Strunk, O., Westram, R., Richter, L., Meier, H., Yadhukumar, Buchner, A., Lai, T., Steppi, S. \& other authors (2004). ARB: a software environment for sequence data. Nucleic Acids Res 32, 1363-1371.

Oren, A. (2006). The order Halobacteriales. In The Prokaryotes: a Handbook on the Biology of Bacteria, 3rd edn, vol. 3, pp. 113-164. Edited by M. Dworkin, S. Falkow, E. Rosenberg, K. H. Schleifer \& E. Stackebrandt. New York: Springer.

Oren, A. \& Ventosa, A. (2000). International Committee on Systematic Bacteriology Subcommittee on the taxonomy of Halobacteriaceae. Minutes of the meetings, 16 August 1999, Sydney, Australia. Int J Syst Evol Microbiol 50, 1405-1407.

Oren, A., Ventosa, A. \& Grant, W. D. (1997). Proposed minimal standards for description of new taxa in the order Halobacteriales. Int J Syst Bacteriol 47, 233-238.

Oren, A., Elevi, R., Watanabe, S., Ihara, K. \& Corcelli, A. (2002). Halomicrobium mukohataei gen. nov., comb. nov., and emended description of Halomicrobium mukohataei. Int J Syst Evol Microbiol 52, 1831-1835.

Tamaoka, J. (1994). Determination of DNA base composition. In Chemical Methods in Prokaryotic Systematics, pp. 463-470. Edited by M. Goodfellow \& A. G. O’Donnell. Chichester: Wiley.

Torreblanca, M., Rodriguez-Valera, F., Juez, G., Ventosa, A., Kamekura, M. \& Kates, M. (1986). Classification of non-alkaliphilic halobacteria based on numerical taxonomy and polar lipid composition, and description of Haloarcula gen. nov. and Haloferax gen. nov. Syst Appl Microbiol 8, 89-99. 